\title{
IMPACT OF SOIL MANAGEMENT ON BIODIVERSITY OF EPIGEIC GROUPS
}

\author{
IVANiČ Porhajašová, J..$^{*}$ - PetroviČOvÁ, K. ${ }^{1}$ - MlynekovÁ, E. ${ }^{2}$ - ERnst, D. ${ }^{3}$ - BabošovÁ, \\ M. ${ }^{1}$ - NOSKOVIČ, J. ${ }^{1}$ - KRUMPÁLOVÁ, Z. ${ }^{4}$ \\ ${ }^{I}$ Department of Environment and Zoology, Faculty of Agrobiology and Food Resources \\ Slovak University of Agriculture in Nitra, Tr. A. Hlinku 2, 94976 Nitra, Slovak Republic \\ (phone: +421-37-641-4470) \\ ${ }^{2}$ Department of Animal Husbandry, Faculty of Agrobiology and Food Resources \\ Slovak University of Agriculture in Nitra, Tr. A. Hlinku 2, 94976 Nitra, Slovak Republic \\ ${ }^{3}$ Department of Crop Production, Faculty of Agrobiology and Food Resources \\ Slovak University of Agriculture in Nitra, Tr. A. Hlinku 2, 94976 Nitra, Slovak Republic \\ ${ }^{4}$ Department of Ecology and Environmental Science, Faculty of Natural Sciences \\ Constantine the Philosopher University in Nitra, Tr. A. Hlinku 1, 94901 Nitra, Slovak Republic \\ "Corresponding author \\ e-mail: Jana.Porhajasova@uniag.sk; phone:+421-37-641-4470 \\ (Received 22 $2^{\text {nd }}$ May 2019; accepted $25^{\text {th }}$ Oct 2019)
}

\begin{abstract}
The aim of this study was to assess the effect of ecological and integrated farming on the occurrence of epigeic animal groups. The earth trap method was used, were exposed in Pisum sativum and Hordeum vulgare. The experiment was performed from 2015 to 2017 at the research fields of the Plant Biology and Ecology Centre in Nitra. During the three-year period, 11,866 exemplars were collected from 21 taxonomic groups. Under integrated farming of 5,456 exemplars belonging to 20 groups were collected, in the ecological farming of 6,410 exemplars belonging to 19 groups were collected. The decreasing tendency of abundance in most groups was recorded. Both types of farming showed the Coleoptera, Acarina, Araneida, Collembola as the highly dominant groups. The Opilionida occurred subdominantly. The occurrence of others was recedent or subrecedent. The presence of these animal groups in the agroecosystem increases its biodiversity. The impact of cultivated crops, temperature and type of farming on occurrence of animal epigeic groups was significant. The impact of precipitation was non-significant. The faunistic similarity was of $85.71 \%$, the identity of dominancy was of $95.57 \%$. The highest value of diversity was recorded in the integrated farming with Pisum sativum, in ecological farming with Hordeum vulgare.
\end{abstract}

Keywords: Coleoptera, ecological farming, ground traps, integreted farming

\section{Introduction}

The soil is an important natural resource, and few phenomena on our planet match the complexities of the processes in it. Farming is the most widely used environ technology with its positive and negative impacts on the land. The agricultural land is a type of modified land with a significant human influence and with a disturbed course of natural processes. Biodiversity loss, an important consequence of agricultural intensification, can lead to reductions in agroecosystem functions and services. Increasing crop diversity through rotation may alleviate these negative consequences by restoring positive aboveground-belowground interactions. Compared to the natural ecosystems, in agroecosystems the biodiversity is more reduced (Tieman et al., 2015), 
but according to Baranová et al. (2015) the artificial habitats often provides the shelter of biodiversity in anthropogenic land, because of its valuable natural biotope analogs.

One of the indicators reflecting the biotope burden is soil edaphone, which is an important component of biocoenosis and an important bioindicator of environmental quality. Fazekašová and Bobul'ovská (2012) reported that communities of soil organism play an irreplaceable role in decomposition of organic matter, in cycle of biogenic elements of carbon, nitrogen, sulfur, phosphorus, in transformation and degradation of waste and toxic substances, etc. and its presence is irreplaceable. Afterwards, the impact of soil organisms becomes a key component of the strategy leading to the sustainability of the soil ecosystem. The biodiversity of epigeic groups, including its abundance in soil, directly depends on the abiotic and biotic factors that are typical of the biotope. In the agroecosystems, in addition to the natural factors, there is also a strong human impact, such as soil cultivation, crop rotation, cultivated crop, organic and artificial fertilizer inputs, and more. These interventions affect the level of agroecosystems biodiversity and contributes mainly to the reduction of the edaphic groups abundance (Baranová et al., 2013; Porhajašová et al., 2013).

In general, floristic and faunistic biodiversity in ecological farming systems is higher than in integrated systems. However, if integrated systems are well managed, it can also improve the biodiversity in agricultural areas (Bavec and Bavec, 2014; Dobrovodská et al., 2019).

The aim of this study was to asses the epigeic groups biodiversity in stands of Pisum sativum and Hordeum vulgare cultivated under the conditions of ecological and integrated farming.

\section{Materials and methods (Experimental)}

The collection of epigeic material was carried out by the earth traps method in 2015 to 2017 during the growing season (April to October) in stands of Pisum sativum and Hordeum vulgare cultivated under the conditions of ecological and integrated farming. Both types of management are governed by the following principles. Integrated management is based on ensuring sustainable management, achieving higher quality yields without burdening the environment, maintaining or improving soil fertility, a consistent system approach to all cultivation technology to optimize the economic and environmental aspects of production. Organic farming is based on the assumption that crops use natural resources, for example to combat pests, maintain or increase soil fertility, etc. Without resorting to synthetic chemicals such as fertilizers, pesticides, antibiotics, and without the use of any organisms that have been genetically modified. In this way, more natural, healthier and nutritious foods are obtained. In addition, it helps to achieve greater environmental sustainability, with minimal impact on the environment. One earth trap was located in the center of the plot is exposed in the crops under investigation. A solution of $4 \%$ formaldehyde was used as a fixing liquid. Traps were collected at monthly intervals (once a month), the collected biological material was determined in the department's conditions according to keys (Hůrka, 1996; Pokorný, 2002, 2004).

Epigeic groups of monitored agroecosystems were evaluated on the basis of abundance, dominance and species identity according to Jaccard (IA), dominance identity according to Renkonnen and on the basis of diversity degree according to 
Shannon-Weaver $\left(\mathrm{H}^{\prime}\right)$ (Losos et al., 1994). Prediction of the richness of edaphic animal species was performed and the homeostasis of agroecosystems was evaluated.

\section{Study area}

The monitored area is located in the western part of the Žitava upland on the site of Nitra - Dolná Malanta (research fields of the Plant Biology and Ecology Centre, the Faculty of Agrobiology and Food Resources of the Slovak University of Agriculture, GPS $48^{\circ} 31^{\prime} \mathrm{N}, 18^{\circ} 14^{\prime} \mathrm{E}$ ) in the lower part of the Selenec stream and its tributaries (Hrnčiarová, 2001), (Fig. 1). The altitude of monitored area is of 175 to $180 \mathrm{~m}$ above sea level.

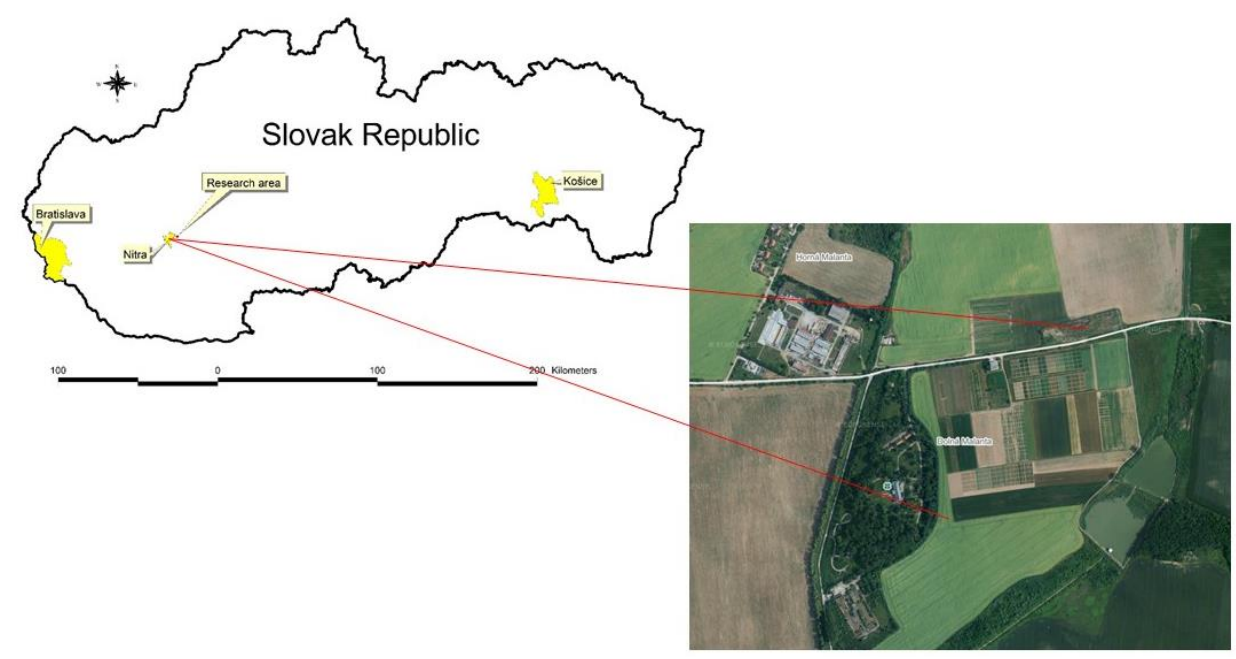

Figure 1. Map of study area-Dolná Malanta

The research was performed in stands of Pisum sativum and Hordeum vulgare cultivated under the conditions of ecological and integrated farming. Legumes have a lower autoregulatory and compensatory ability than cereals. Therefore, good soil preparation, soil types and agroecological conditions play an important role in pea cultivation technology (Candráková, 2014; Černý et al., 2017).

\section{Data analyses}

Diversity and equitability were calculated using the Shannon Diversity Index $-\mathrm{H}^{\prime}$ by PAST software (Hammer, 2015).

The prediction - rarefaction of the richness of edaphic animal groups was performed by the PAST software using a confidence interval of $95 \%$ based on the amount of caught dragonfly material in the Pisum sativum and Hordeum vulgare stands cultivated under the conditions of ecological and integrated farming.

The data distribution normality of the individuals of animal epigeic groups from monitored areas was tested by the Shapiro-Wilks W test. Due to the violation of the data distribution normality, non-parametric tests - Friedman (ANOVA) and Kruskal-Wallis test (ANOVA) were used to $\mathrm{H}_{0}$ hypotheses testing. We observed the influence of factors (temperature, total rainfall, management (integrated, ecological), type of cultivated crop (Pisum sativum, Hordeum vulgare)) on the number of individuals of individual epigeic 
groups. Post hot test (LSD test) we added statistical significance of pairs in combination year, farming, plant in Friedman's test. $\mathrm{H}_{0}$ hypotheses were tested at the significance level of $\mathrm{p} \alpha=0.05$ (if $\mathrm{p}>\mathrm{p} \alpha$, we cannot reject $\mathrm{H}_{0}$ at the level of selected statistical significance of $\mathrm{p} \alpha=0.05$ ) (i) random selection comes from a normal distribution file, (ii) the number of individuals of the animal epigeic groups does not differ due to the type of farming and the type of crop cultivated, (iii) the average monthly temperature had not an effect on the number of individuals in the animal epigeic groups, (iiii) the average monthly precipitation had not an effect on the number of individuals in the animal epigeic groups. The data matrix with the number of individuals of the all animal epigeic groups was used.

To the data analysis the statistical program Statistics $\mathrm{Cz}$, version 7.0 was used (StatSoft, Inc.).

\section{Results and Discussion}

The exemplars of 11,866 pieces of the animal epigeic groups belonging to 21 taxonomic groups, which are part of the zoological taxonomic unit Arthropoda, during the three-year period were collected. Of the number of individuals obtained, 5,456 individuals belonging to 20 groups were collected within under the integrated farming conditions. Exemplars of 6,410 pieces belonging to 19 taxonomic groups were collected in the ecological farming (Tables 1, 2). Muridae and Larvae were not further determined, it represented the developmental stages of the epigeic groups present.

Table 1. Integrated farming - abundance and dominance of animal epigeic groups in Pisum sativum and Hordeum vulgare stands

\begin{tabular}{|c|c|c|c|c|c|c|c|c|c|c|c|c|}
\hline \multirow{2}{*}{ Epigeic group } & \multicolumn{5}{|c|}{ Pisum sativum } & \multicolumn{5}{|c|}{ Hordeum vulgare } & \multirow[b]{2}{*}{$\sum^{* *}$} & \multirow[b]{2}{*}{$D *(\%)$} \\
\hline & 2015 & 2016 & 2017 & $\sum * *$ & $D *(\%)$ & 2015 & 2016 & 2017 & $\sum * *$ & $D *(\%)$ & & \\
\hline Anura & 2 & - & - & 2 & 0.08 & 4 & - & - & 4 & 0.13 & 6 & 0.11 \\
\hline Acarina & 565 & 222 & 144 & 931 & 37.16 & 524 & 372 & 54 & 950 & 32.19 & 1881 & 34.47 \\
\hline Araneida & 112 & 46 & 86 & 244 & 9.74 & 128 & 43 & 56 & 227 & 7.69 & 471 & 8.63 \\
\hline Auchenorrhyncha & 8 & 5 & 4 & 17 & 0.67 & 7 & 4 & 6 & 17 & 0.58 & 34 & 0.65 \\
\hline Coleoptera & 279 & 337 & 327 & 943 & 37.66 & 521 & 407 & 191 & 1119 & 37.94 & 2062 & 37.79 \\
\hline Collembola & 53 & 35 & 14 & 102 & 4.07 & 116 & 150 & 23 & 289 & 9.79 & 391 & 7.16 \\
\hline Dermaptera & 14 & - & 15 & 29 & 1.17 & 13 & 11 & 11 & 35 & 1.18 & 64 & 1.17 \\
\hline Diplopoda & 18 & 13 & 14 & 45 & 1.78 & 20 & 26 & 8 & 54 & 1.84 & 99 & 1.83 \\
\hline Diptera & 2 & 1 & 4 & 7 & 0.29 & 8 & 3 & 3 & 14 & 0.47 & 21 & 0.38 \\
\hline Formicoidea & 33 & 7 & 2 & 42 & 1.67 & 40 & 15 & - & 55 & 1.86 & 97 & 1.78 \\
\hline Hymenoptera & 2 & 7 & 6 & 15 & 0.58 & 12 & 6 & 6 & 24 & 0.81 & 39 & 0.73 \\
\hline Chilopoda & 4 & - & 3 & 7 & 0.28 & 2 & 3 & 3 & 8 & 0.27 & 15 & 0.27 \\
\hline Isopoda & 8 & 7 & 3 & 18 & 0.75 & 2 & 7 & 4 & 13 & 0.44 & 31 & 0.57 \\
\hline Lacertidae & - & 1 & - & 1 & 0.04 & - & - & - & - & - & 1 & 0.01 \\
\hline Larvae & 3 & 2 & 5 & 10 & 0.39 & 8 & 3 & 6 & 17 & 0.57 & 27 & 0.49 \\
\hline Lumbricidae & 2 & 5 & 1 & 8 & 0.32 & 6 & 2 & - & 8 & 0.28 & 16 & 0.28 \\
\hline Opilionida & 17 & 22 & 45 & 84 & 3.35 & 31 & 26 & 60 & 117 & 3.96 & 201 & 3.68 \\
\hline$\sum * *$ & 1122 & 710 & 673 & 2505 & 100 & 1442 & 1078 & 431 & 2951 & 100 & 5456 & 100 \\
\hline
\end{tabular}

$\left(D^{*}-\right.$ dominance; $\sum^{* *}-$ total $)$ 
Table 2. Ecological farming - abundance and dominance of animal epigeic groups in Pisum sativum and Hordeum vulgare stands

\begin{tabular}{|c|c|c|c|c|c|c|c|c|c|c|c|c|}
\hline \multirow{2}{*}{ Epigeic group } & \multicolumn{5}{|c|}{ Pisum sativum } & \multicolumn{5}{|c|}{ Hordeum vulgare } & \multirow[b]{2}{*}{$\sum^{* *}$} & \multirow[b]{2}{*}{$D *(\%)$} \\
\hline & 2015 & 2016 & 2017 & $\sum * *$ & $D *(\%)$ & 2015 & 2016 & 2017 & $\sum * *$ & $D *(\%)$ & & \\
\hline Acarina & 763 & 321 & 116 & 1200 & 32.19 & 569 & 372 & 119 & 1060 & 39.51 & 2260 & 35.26 \\
\hline Araneida & 159 & 32 & 47 & 238 & 6.38 & 123 & 29 & 44 & 196 & 7.31 & 434 & 6.77 \\
\hline Auchenorrhyncha & 2 & - & 3 & 5 & 0.13 & 3 & 6 & 6 & 15 & 0.57 & 20 & 0.31 \\
\hline Coleoptera & 955 & 416 & 359 & 1730 & 46.42 & 252 & 412 & 189 & 853 & 31.79 & 2583 & 40.29 \\
\hline Collembola & 91 & 110 & 11 & 212 & 5.68 & 81 & 99 & 28 & 208 & 7.75 & 420 & 6.55 \\
\hline Dermaptera & 11 & 8 & 41 & 60 & 1.61 & 8 & & 43 & 51 & 1.9 & 111 & 1.73 \\
\hline Diplopoda & 18 & 11 & 10 & 39 & 1.07 & 22 & 21 & 6 & 49 & 1.83 & 88 & 1.37 \\
\hline Diptera & 4 & 5 & 1 & 10 & 0.27 & 9 & 6 & 5 & 20 & 0.75 & 30 & 0.47 \\
\hline Formicoidea & 41 & 4 & 10 & 55 & 1.47 & 18 & 21 & 16 & 55 & 2.05 & 110 & 1.72 \\
\hline Heteroptera & - & - & - & - & - & - & 3 & - & 3 & 0.11 & 3 & 0.05 \\
\hline Hymenoptera & 4 & 5 & 4 & 13 & 0.35 & 7 & 6 & 13 & 26 & 0.98 & 39 & 0.61 \\
\hline Chilopoda & 2 & - & - & 2 & 0.05 & - & - & 5 & 5 & 0.18 & 7 & 0.11 \\
\hline Isopoda & 4 & 5 & 2 & 11 & 0.29 & 9 & 3 & 2 & 14 & 0.52 & 25 & 0.39 \\
\hline Larvae & 8 & 1 & 4 & 13 & 0.35 & 6 & 3 & 4 & 13 & 0.48 & 26 & 0.41 \\
\hline Lumbricidae & 9 & 4 & 1 & 14 & 0.38 & 3 & 4 & - & 7 & 0.25 & 21 & 0.32 \\
\hline Opilionida & 38 & 38 & 34 & 110 & 2.95 & 25 & 33 & 40 & 98 & 3.65 & 208 & 3.24 \\
\hline Orthoptera & 4 & - & 3 & 7 & 0.18 & - & 4 & - & 4 & 0.15 & 11 & 0.17 \\
\hline Siphonaptera & - & 8 & - & 8 & 0.23 & - & 6 & - & 6 & 0.22 & 14 & 0.23 \\
\hline$\sum * *$ & 2113 & 968 & 646 & 3727 & 100 & 1135 & 1028 & 520 & 2683 & 100 & 6410 & 100 \\
\hline
\end{tabular}

Acarina and Coleoptera were assessed as an eudominant groups in both types of farming and in both crops cultivated. Araneida and Collembola were dominant (Tables 1, 2). With integrated farming in stands of Pisum sativum, the dominant group was Araneida. In the Hordeum vulgare stands the Araneida and Collembola were dominant. With ecological farming, the Araneida and Collembola groups were dominant in both crops cultivated. The occurrence of Acarina is limited by many factors, especially by its dependence on the substrate type. Gormsen et al. (2006) states that the ending of agricultural measures, i.e. soil management is associated with an increase of the Acarina population. Fox et al. (2017) confirmed the increase of Acarina abundance in soil with application of organic fertilizers. Authors also confirmed higher number of Acarina in soil with shallow ploughing than in soil with deep ploughing applied. According to Boháč et al. (2015), the Coleoptera represents a large and functionally dominant group of soil macrofauna, which sensitively reacts to anthropogenic activity in forest but also in non-forest habitats. Coleoptera, especially Carabidae, represent an important bioindicating organisms in both artificial and natural ecosystems. Authors Tieman et al. (2015) and Vician et al. $(2011,2018)$ state that the main factors affecting the diversity of its communities are elements of environment such as vegetation, humidity, temperature and shadow. Migration of Coleoptera is significantly affected by microclimatic conditions of the habitat. According to Baranová et al. (2013), the species variability of Carabidae (Coleoptera) is mainly influenced by soil moisture, herbal stratum of 0-200 mm, intensity of agrotechnical interventions and 
humus content. Carabidae (Coleoptera) react sensitively to the toxic substances (herbicides, insecticides), $\mathrm{pH}$ change and soil moisture and to the excessive use of artificial fertilizers (Vician et al., 2011; Tieman et al., 2015; Nietupski et al., 2015). In agroecosystems, macropterous species of Carabidae (Coleoptera) with a smaller body size are predominate. It is an indicator of lower ecological stability of the agroecosystems (Langraf et al., 2017, 2018, 2019). The abundance of Araneida and Collembola was almost equal in both monitored types of farming. According to Vician et al. (2015), the arachnocenosis are most sensitive to insecticide application and soil cultivation. During the monitored years, the abundance of Araneida and Collembola in both cultivated crops decreased. The most frequent occurrence of these groups was recorded in 2015, which is probably related to the appropriate climatic conditions of the environment (temperature and precipitation). In the integrated farming system, reducing the number of agrotechnical interventions affects the increase of Araneida and Coleoptera abundance. The population of Collembola varies in abundance and species representation, depending on the type of vegetation and soil conditions. The impact of agricultural management, such as crop harvesting, insecticide and herbicide application and conventional ploughing, has a significant negative effect on the occurrence of Collembola, but the application of organic fertilizers has a positive effect on the increase of its populations (Querner et al., 2008; Jasinski et al., 2016). The subdominant representation in both types of crops and in both types of farming was recorded with Opilionida. Recedent representation was recorded with groups of Dermaptera, Diplopoda and Formicoidea. The others groups were subrecedent. Even though its low presence, its importance in ecosystems is irreplaceable (e.g. Heteroptera are involved in the elimination of acarinocenoses and Thysanoptera, Orthoptera regulates insect pests, Diplopoda are an important saprophytophages, Dermaptera performs the function as a saprophages to polyphagous nocturnal insects). Presence of this epigeic groups contributes to the biodiversity of agroecosystems and also to its ecological stability. It showed that also intensively exploited agroecosystems allow the existence of a relatively wide range of zoofauna. Recorded epigeic groups represents a diversified component of soil fauna. These groups are characterized by different adaptations to the soil environment and different sensitivity to the stress (Porhajašová et al., 2012). The abundance and biodiversity of these epigeic groups supports the natural conditions of ecosystems (Kalivoda et al., 2010; Swaminathan, 2014). According to Lenoir and Lennartsson (2010) believe that the high abundance and dominance of Coleoptera, Araneida and Formicoidae in agroecosystems is mainly related to its trophic preference and tolerance to the soil environment.

In addition to the quantitative evaluation of the obtained epigeic material, qualitative indicators were identified. The qualitative composition of populations influences mainly the vegetation cover, abiotic and biotic environmental factors in the form of intraspecies and inter-species relationships which depends on environmental conditions.

Based on the calculated values of faunistic similarity (85.71\%), when two types of farming were compared, it can be stated that the ecological and integrated farming are the similar types of ecosystems.

Based on the dominance of populations mutual in both cultivation systems, the dominance identity value was of $95.57 \%$.

The diversity value in the Pisum sativum stands cultivated under the conditions of integrated farming was of $\mathrm{H}^{\prime}=2.61\left(\mathrm{H}^{\prime} \min =2.56, \mathrm{H}^{\prime} \max =2.65\right)$, in the ecological farming it was of $\mathrm{H}^{\prime}=2.40\left(\mathrm{H}^{\prime} \min =2.36, \mathrm{H}{ }^{\prime} \max =2.44\right)$. In the stands of 
Hordeum vulgare, the value of diversity in integrated farming reached of $\mathrm{H}^{\prime}=2.62$ $\left(\mathrm{H}^{\prime} \min =2.57, \mathrm{H}^{\prime} \max =2.66\right)$, in ecological farming it was of $\mathrm{H}^{\prime}=2.67\left(\mathrm{H}^{\prime} \min =2.61\right.$, $\mathrm{H}$ 'max $=2.71$ ).

The equitability value is in the range of $\mathrm{e}=0-1$, more balanced communities has an equitability value reaching of 1 . The value of equitability in the Pisum sativum integrated cultivation system was of $\mathrm{e}=0.68$, in the Hordeum vulgare $\mathrm{e}=0.69$; in ecological cultivation system of Pisum sativum e $=0.63$, in Hordeum vulgare e $=0.70$. The equitability values are relatively low, reflecting imbalances number of specimens represented by individual taxa.

On the basis of the total species richness of the taxa of all the areas studied (the number of individuals), the prediction of the richness of animal epigeic groups of the monitored areas was predicted by the individual rarefraction with confidence interval of 95\% (Fig. 2).

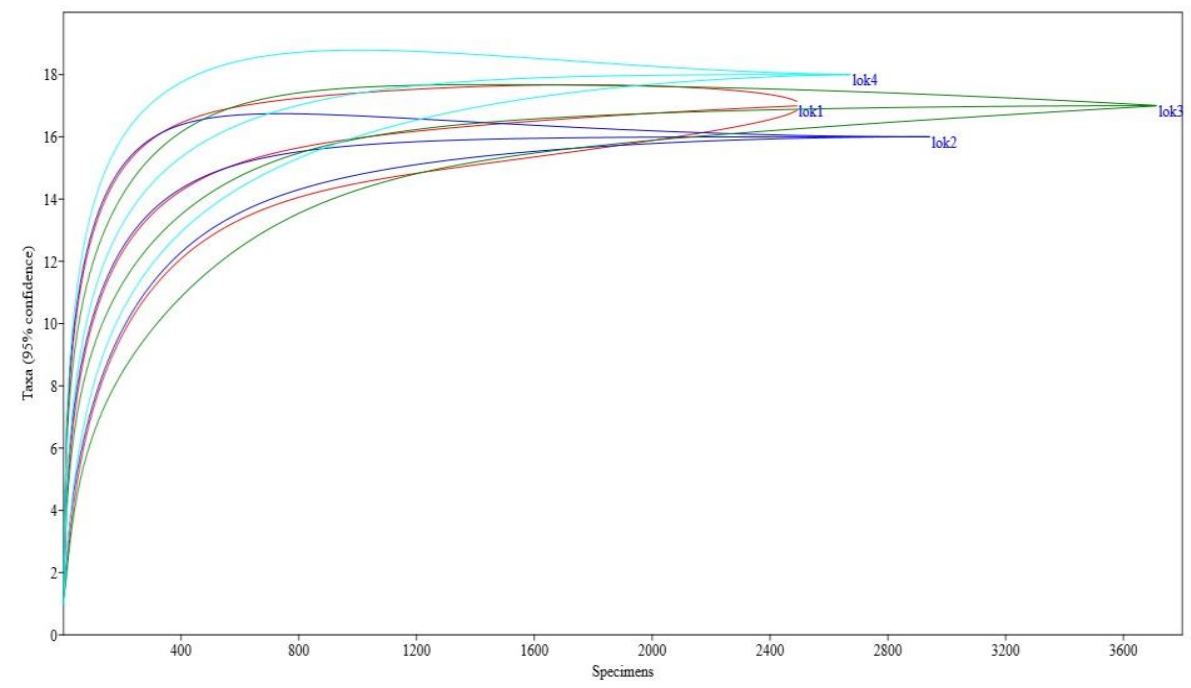

Figure 2. Rarefaction curves of prediction of animal epigeic groups in integrated Pisum sativum (lok 1), Hordeum vulgare (lok 2) and ecological farming Pisum sativum (lok 3) a Hordeum vulgare (lok 4)

The length of the rarefaction curve is a reflection of row saturation and prediction confidence. The cultivated area of Pisum sativum under the ecological farming $(\mathrm{N}=$ 3,727 individuals, 17 animal groups, predicted 18) had the longest rarefaction curve, indicating a greater predictive value for the prediction. According to experimental results, this site had the most complete spectrum of animal epigeic groups. Locations in stands of Pisum sativum ( $\mathrm{N}=2,505$ individuals, confirmed 17, predicted 17 animal groups) and Hordeum vulgare $(\mathrm{N}=2,951$ individuals, confirmed 16 , predicted 17 animal groups) with integrated farming and locality in stands of Hordeum vulgare $(\mathrm{N}=$ 2,683 individuals, confirmed 18, predicted 19 animal epigeic groups) with ecological farming were characterized by a short rarefaction curves, reflecting a reserve in animal epigeic saturation and a higher degree of prediction uncertainty. According to Litavský et al. (2018), Vician et al. (2015) and Filho et al. (2016) reported that the presence of epigeic groups in the soil in different types of ecosystems is mainly related to its trophic preference, but also to its tolerance to particular habitat conditions. 
Using the non-parametric Friedman test, the effect of the farming method and the type of cultivated crop on the number of individuals of the animal epigeic groups was tested (H0: the number of individuals of animal epigeic groups was not differ due to the type of farming and type of cultivated crop, $p \alpha=0.05$ ). The result of the test is of $\mathrm{p}=0.00, \mathrm{H} 0$ is rejected at a significance level of $95 \%$. Our experimental data showed that the farming and crop cultivated type had an impact on the number of individuals of animal epigeic groups (Fig. 3).

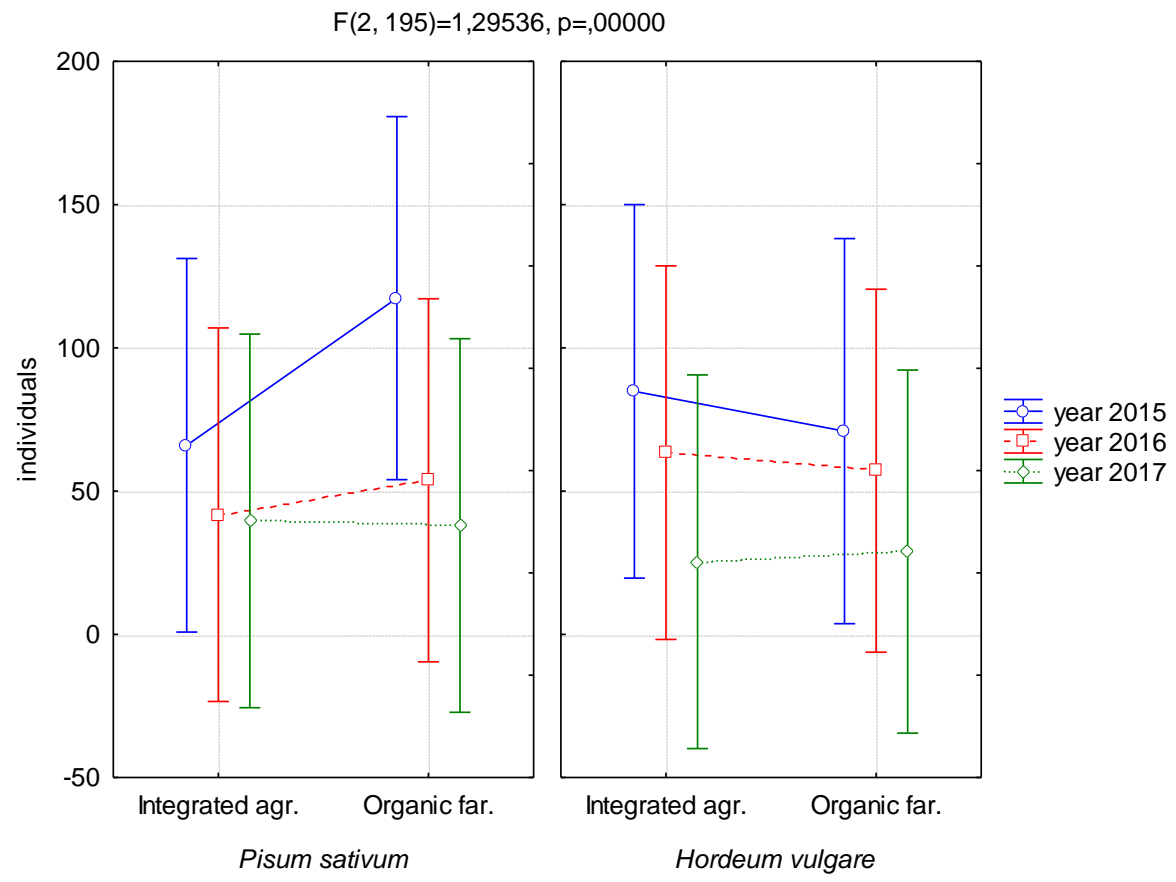

Figure 3. Impact of farming and crop cultivated type on the number of individuals of animal epigeic groups

By the Post hot test we have identified which management pairs differ at the level of statistical significance $(\mathrm{p} \alpha=0.05)$ during the years $2015-2017(\mathrm{p}<0.05)$. The results are shown in Table 3.

In the stands of Pisum sativum cultivated under the conditions of ecological farming, an average number of individuals was higher than in the same crop cultivated under the conditions of integrated farming. However, in the stands of Hordeum vulgare cultivated under the conditions of integrated farming, an average number of individuals was higher.

In view of the impact of the cultivated crop (Pisum sativum, Hordeum vulgare) on the occurrence of animal epigeic groups, it is mainly the creation of suitable conditions, shading, moisture, realized agrotechnical interventions during crop cultivation, etc.

Using the non-parametric Kruskal-Wallis test, the effect of the average monthly temperature on the number of individuals of animal epigeic groups was tested (H0: the average monthly temperature had not an effect on the number of individuals of animal epigeic groups, $p \alpha=0.05$ ). The result of the test is of $\mathrm{p}=0.01, \mathrm{H} 0$ is rejected at a significance level of $95 \%$. Our experimental data showed that the average monthly temperature had an impact on the number of individuals of animal epigeic groups during the research period (Fig. 4). 
Table 3. Results of Post hot test

\begin{tabular}{|c|c|c|c|c|c|c|c|c|c|c|c|c|}
\hline & 1 & 2 & 3 & 4 & 5 & 6 & 7 & 8 & 9 & 10 & 11 & 12 \\
\hline 1 & - & 0.69 & 0.03 & 0.92 & 0.05 & 0.96 & 0.79 & 0.85 & 0.05 & 0.39 & 0.05 & 0.42 \\
\hline 2 & 0.69 & - & 0.48 & 0.77 & 0.36 & 0.65 & 0.50 & 0.55 & 0.33 & 0.02 & 0.32 & 0.02 \\
\hline 3 & 0.03 & 0.48 & - & 0.32 & 0.10 & 0.24 & 0.16 & 0.19 & 0.09 & 0.05 & 0.09 & 0.05 \\
\hline 4 & 0.92 & 0.77 & 0.32 & - & 0.54 & 0.87 & 0.71 & 0.77 & 0.51 & 0.03 & 0.49 & 0.04 \\
\hline 5 & 0.05 & 0.36 & 0.10 & 0.54 & - & 0.64 & 0.79 & 0.74 & 0.96 & 0.71 & 0.94 & 0.78 \\
\hline 6 & 0.96 & 0.65 & 0.24 & 0.87 & 0.64 & - & 0.83 & 0.89 & 0.61 & 0.04 & 0.59 & 0.05 \\
\hline 7 & 0.05 & 0.50 & 0.16 & 0.71 & 0.79 & 0.83 & - & 0.94 & 0.76 & 0.54 & 0.73 & 0.58 \\
\hline 8 & 0.85 & 0.55 & 0.19 & 0.77 & 0.74 & 0.89 & 0.94 & - & 0.70 & 0.04 & 0.68 & 0.05 \\
\hline 9 & 0.05 & 0.33 & 0.09 & 0.51 & 0.96 & 0.61 & 0.76 & 0.70 & - & 0.76 & 0.97 & 0.82 \\
\hline 10 & 0.39 & 0.02 & 0.05 & 0.03 & 0.73 & 0.04 & 0.54 & 0.04 & 0.76 & - & 0.79 & 0.94 \\
\hline 11 & 0.05 & 0.32 & 0.09 & 0.49 & 0.94 & 0.59 & 0.73 & 0.68 & 0.97 & 0.79 & - & 0.84 \\
\hline 12 & 0.42 & 0.02 & 0.05 & 0.04 & 0.78 & 0.05 & 0.58 & 0.05 & 0.82 & 0.94 & 0.84 & - \\
\hline
\end{tabular}

Comments: $1=$ the year 2015 , integrated farming, Pisum sativum; $2=$ the year 2015 , integrated farming, Hordeum vulgare; $3=$ the year 2015, ecological farming, Pisum sativum; $4=$ the year 2015, ecological farming, Hordeum vulgare; $5=$ the year 2016, integrated farming, Pisum sativum; $6=$ the year 2015, integrated farming, Hordeum vulgare; $7=$ the year 2016, ecological farming, Pisum sativum; $8=$ the year 2016, ecological farming, Hordeum vulgare; $9=$ the year 2017, integrated farming, Pisum sativum; $10=$ the year 2017, integrated farming, Hordeum vulgare; $11=$ the year 2017 , ecological farming, Pisum sativum; 12 = the year 2017, ecological farming, Hordeum vulgare

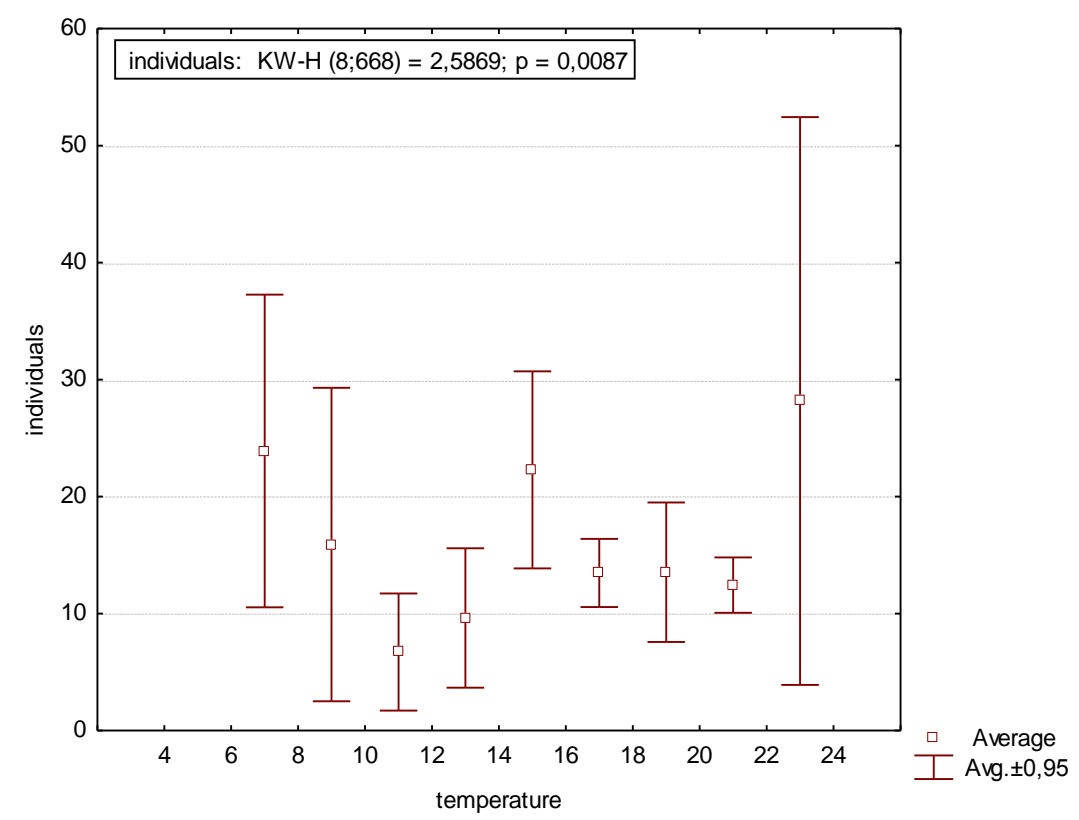

Figure 4. Impact of average monthly temperature on the number of individuals of animal epigeic groups

The impact of the average monthly precipitation on the number of individuals of animal epigeic groups (H0: average monthly precipitation had not an effect on the number of individuals of animal epigeic groups, $\mathrm{p} \alpha=0.05$ ) was also tested by the Kruskal-Wallis test. The result of the test is of $\mathrm{p}=0.34, \mathrm{H} 0$ is not rejected at a significance level of $95 \%$. Our experimental data showed that the average monthly precipitation had not an impact on the number of individuals of animal epigeic groups during the research period (Fig. 5). 


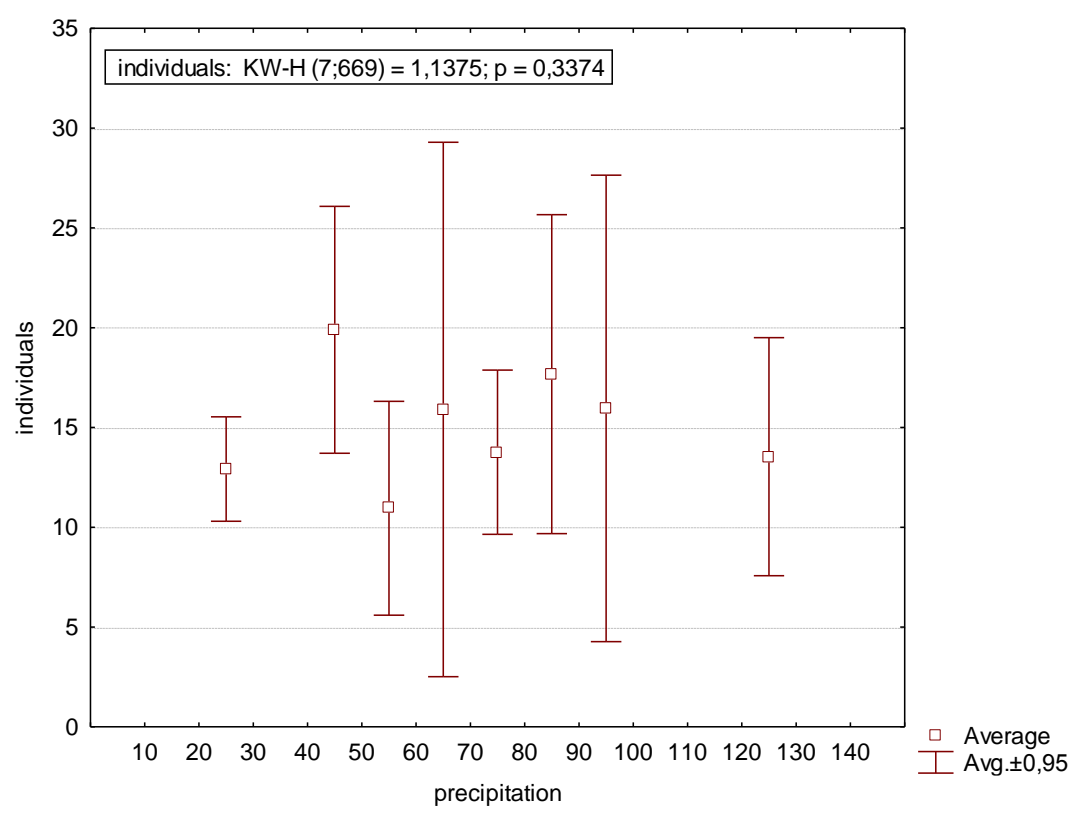

Figure 5. Impact of average monthly precipitation on the number of individuals of animal epigeic groups

\section{Conclusions}

The impact of two types of farming, integrated and ecological, on the occurence of animal epigeic groups was monitored during the three-year period. The individuals of 11,866 pieces belonging to 21 taxonomic groups were collected. Within the integrated farming of 5,456 individuals, with the determination of 20 groups, within the ecological farming of 6,410 individuals belonging to 19 groups. Coleoptera, Acarina, Araneida and Collembola were dominant in the both types of farming. The occurrence of Opilionida was subdominant. The occurrence of Dermaptera, Diplopoda, Formicoidea, Isopoda, Lumbricidae and others was evaluated as recedent and subrecedent. The impact of cultivated crop, temperature and the type of farming on animal epigeic groups was significant. The impact of precipitation was non-significant. According to different types of farming comparison, the faunistic similarity was of $85.71 \%$, the dominance identity of $95.57 \%$. The higher value of diversity was recorded in integrated farming with Pisum sativum, in ecological farming with Hordeum vulgare. In conclusion, the abiotic and biotic environmental factors had an effect on the qualitative composition of present animal populations.

Acknowledgements. This research is supports by the project KEGA 021SPU-4/2017.

\section{REFERENCES}

[1] Baranová, B., Fazekašová, D., Jászay, T., Manko, P. (2013): Ground beetle (Coleoptera: Carabidae) community of arable land with different crops. - Folia Faunistica Slovaca 18(1): 21-29. 
[2] Baranová, B., Manko, P., Jászay, T. (2015): Waste dumps as local biodiversity hotspots for soil macrofauna and ground beetles (Coleoptera:Carabidae) in the agricultural landscape. - Ecological Engineering 81: 1-13.

[3] Bavec, M., Bavec, F. (2014): Impact of Organic Farming on Biodiversity. - In: Lo, Y. H., Blanco, J. A., Shovonlal, R. (eds.) Biodiversity in Ecosystems. Linking Structure and Function. https://doi.org/10.5772/58974.

[4] Boháč, J., Jahnová, Z. (2015): Land Use Changes and Lanscape Degradation in Central and Eastern Europe in the Last Decades: Epigeic Ivertebrates as Bioindicators of Landscape Changes. - In: Arman, R. H., Hanninen, O. (eds.) Environmental Indicators 395-419.

[5] Candráková, E. (2014): Preparing of the soil under Pisum sativum. http://www.agroporadenstvo.sk/rastlinna-vyroba-strukoviny?article=384. Accessed on 23 January 2019.

[6] Černý, I., Pačuta, V., Ernst, D., Gažo, J. (2017): Dependence of yield formation and sugar content on sugar beet varieties and annual agroecological conditionns. - Listy cukrovarnické a řepařské 133(12): 379-384.

[7] Dobrovodská, M., Kanka, R., David, S., Kolár, J., Špulerová, J., Štefunková, D., Mojses, M., Petrovič, F., Krištín, A., Stašiov, S., Halada, L., Gajdoš, P. (2019): Assessment of the biocultural value of traditional agricultural landscape on a plot-by-plot level: case studies from Slovakia. - Biodiversity and Conservation 28(10): 2615-2645.

[8] Fazekašová, D., Bobul'ovská, L. (2012): Soil organisms as an Indicator of Quality and Environmental Stress in the Soil Ecosystem. - Environment 46(2): 103-106.

[9] Filho, L. C., Filho, O. K., Baretta, D., Tanaka, C. A., Sonsa, J. P. (2013): Collembola Community Structure as a Tool to Assess Land Use Effects on Soil Quality. - Rev. Bras. Cienc. Solo 40: 1-17.

[10] Fox, C. A., Miller, J. J., Joschko, M., Drury, C. F., Reynolds, W. D. (2017): Earthworm population dynamics as a consequence of long-term and recently imposed tillage in a clay loam soil. - Can. J. Soil. Sci 97(4): 561-579.

[11] Gormsen, D., Hedlung, K., Wang, H. F. (2006): Diversity of soil mite communities when managing plant communities on set-aside arable land. - Aplied Soil Ecology 31(1-2): 147-158.

[12] Hammer, Q. (2015): Past Paleontological Statistics Version 3.05. - Reference manual [CD]. University of Oslo: Natural History Museum.

[13] Hrnčiarová, T. (2001): Ecological optimization of agricultural landscape (model area Dolná Malanta). - The Bratislava.

[14] Hůrka, K. (1996): Carabidae of the Czech and Slovak Republics. - Kabourek Zlín.

[15] Jasinski, M., Twardowski, J., Tendziagolska, E. (2016): The occurrence of soil mesofauna in organic crops. - Jour. of Research and Applications in Agricultural Engineering 61(3): 193-199.

[16] Kalivoda, H., Petrovič, F., Kalivodová, E., Kürthy, A. (2010): Influence of the landscape structure on the butterfly (Lepidoptera, Hesperioidae and Papilionidae) and bird (Aves) taxocenoses in Vel'ké Leváre (SW) Slovakia). - Ekologia Bratislava 29(4): 337-359.

[17] Langraf, V., Petrovičová, K., David, S., Ábelová, M., Schlarmannová, J. (2017): Body volume in ground beetles (Carabidae) reflects biotope disturbance. - Folia Oecologica 44(2): 114-120.

[18] Langraf, V., Petrovičová, K., David, S., Kanská, M., Nozdrovická, J., Schlarmannová, J. (2018): Change Phenotypic Traits in Ground Beetles (Carabidae) Reflects Biotope Disturbance in Central Europe. - J. Entomol. Res. Soc. 20(2): 119-129.

[19] Langraf, V., Petrovičová, K., David, S., Nozdrovická, J., Petrovič, F., Schlarmannová, J. (2019): The Bioindication Evaluation of Ground Beetles (Coleoptera: Carabidae) in Three Forest Biotopes in the Southern Part of Central Slovakia. - Ekologia Bratislava 38(1): 25-36. 
[20] Lenoir, L., Lennartsson, T. (2010): Effects of timing of grazing on arthropod communities in semi-natural grasslands. - Journal of Insect Science 10: 33-42.

[21] Litavský, J., Stašiov, S., Svitok, M., Michalková, E., Majzlan, O., Žarnovičan, H., Fedor, P. (2018): Epigeon communities of harvestmen (Opiliones) in Panonian Basin floodplain forests: an interaction with environmental parameters. - Biologia 73(8): 753-763.

[22] Losos, B., Gulička, J., Lellák, J., Pelikán, J. (1984): Ecology of animals. - SPN Publishing, The Prague.

[23] Nietupski, M., Kosewska, A., Lemkowska, B. (2015): Grassland with calcareous gyttja soil in the Olstan Lake District as specific habitats for ground beetles (Coleoptera: Carabidae). - Baltic Journal of Coleopterology 15(1): 57-70.

[24] Pokorný, V. (2002): Book of Coleoptera. - Paseka Publishing, The Prague.

[25] Pokorný, V., Šifner, F. (2004): Book of Insecta. - Paseka Publishing, The Prague.

[26] Porhajašová, J., Noskovič, J., Babošová, M., Rakovská, A. (2012): Biodiversity of epigeic groups in conditions of growing Salix viminalis L. - Acta Universitatis Prešoviensis LIV(7): 5-13.

[27] Porhajašová, J., Šustek, Z., Noskovič, J., Babošová, M. (2013): The effect of application of organic fertilizers on the Dynamics of occurence of carabid species (Carabidae, Coleoptera). - Journal Central European Agriculture 14(2): 251-272.

[28] Querner, P., Erhard, Ch., Gusenleitner, J. (2008): Collembolla (Insecta). - Checklisten der Fauna Österreichischen Akademie der Wissenschaften, Wien 24: 1-26.

[29] Swaminathan, R. (2014): Ground Beetles (Coleoptera: Carabidae): Their Potential as Bioagents in Agroecosystems. - Basic and Applied Aspects of Biopesticides 12: 225-233.

[30] Tieman, L. K., Grandy, A. S., Atkinson, E. E., Marin-Spiotta, E., McDaniel, M. D. (2015): Crop rotational diversity enhances belowground communities and functions in a agroecosystem. - Ecology Letters 18(8): 761-771.

[31] Vician, V., Stašiov, S., Kočík, K., Hazuchová, L. (2011): The structure of community Coeloptera: Carabidae on various farmed areas in the Podpolanie region and their indication. - Acta Facultatis Ecologiae 24-25: 123-131.

[32] Vician, V., Svitok, M., Kočík, K., Stašiov, S. (2015): The influence of agricultural management on the structure of ground beetle (Coleoptera: Carabidae) assemblages. Biologia 70(2): 240-252.

[33] Vician, V., Svitok, M., Michalková, E., Lukáčik, I., Stašiov, S. (2018): Influence of tree species and soil properties on ground beetle (Coleoptera: Carabidae) communities. - Acta Oecologica 91: 120-126. 